\title{
Factors That Affect Consumption Patterns and Market Demands for Honey in the Kingdom of Saudi Arabia
}

\author{
Sobhy Ismaiel ${ }^{1}$, Safar Al Kahtani1 ${ }^{*}$, Nuru Adgaba ${ }^{2}$, Ahmed A. Al-Ghamdi'2, Abdu Zulail ${ }^{1}$ \\ ${ }^{1}$ Department of Agricultural Economics, College of Food and Agriculture Science, King Saud University, Riyadh, \\ KSA \\ ${ }^{2}$ College of Food and Agriculture Sciences, King Saud University, Riyadh, KSA \\ Email: safark@ksu.edu.sa
}

Received 24 June 2014; revised 25 July 2014; accepted 3 August 2014

Copyright $@ 2014$ by authors and Scientific Research Publishing Inc.

This work is licensed under the Creative Commons Attribution International License (CC BY).

http://creativecommons.org/licenses/by/4.0/

(c) $\underset{\mathrm{EY}}{\mathrm{EY}}$ Open Access

\section{Abstract}

Despite the significant annual consumption of honey in Saudi Arabia, information gaps remain with regard to the marketing and market structure of honey along the value chain. This study analyzed the major factors that influenced the consumption, expenditure patterns, and demand of honey in Saudi Arabia. This study forecasted the near-future expected market demands for honey in Saudi Arabia by collecting and analyzing the primary data using questionnaires. A total of 331 respondents from representative regions and large cities were randomly selected and interviewed. The data were analyzed using qualitative and quantitative methods as well as appropriate econometric models. Respondents characterized honey quality using organoleptic words, and these characterizations varied based on the relative significance of perception parameters. Taste, aroma, physical state, and color had aggregated average scores of 4.58, 4.44, 3.54, and 3.28, respectively. In addition to the above parameters, honey source, brand name, and confidence in the producers influenced its perceived quality. The major outlets for honey in Saudi Arabia included producers, specialized honey stores, and auction markets in major cities during the harvesting seasons. Medication, food, and sweetening were the major motivations for buying honey in the Saudi market, with aggregate scores of 4.52, 3.71, and 1.52, respectively. Significant honey price variations were observed within and among different honeys and packaging volumes; this finding might be due to factors such as botanical and geographical origins, package volume size economics (i.e., bulk purchases), honey variety blending, brand names, and producer policies. The average price of locally produced honey was approximately $\$ 73 \mathrm{per} \mathrm{kg}$, which is 10 times more than the average price of honey in the US and the EU. The estimated consumption/income elasticity was 0.27 . These results suggest that honey is a basic commodity in Saudi Arabia. Based on econometric model forecasts,

\footnotetext{
${ }^{*}$ Corresponding author.
} 
the Saudi market demand for honey is expected to reach approximately 29,784 tons in 2025 .

\title{
Keywords
}

\author{
Honey, Consumption Patterns, Demand Forecasting, Honey Quality Elasticity, Marketing \\ Deficiencies
}

\section{Introduction}

As with other food commodities, honey is marketed based on a composite of attributes. Consumers judge the quality based on many factors. These factors might include appearance, organoleptic perception, flavor, taste, texture, color, safety, nutritional value, clear labeling, ingredients, price, packaging, brand reputation, convenience, consistency, origin, ethical aspects, and environmental concerns [1]-[3]. Quality is a relative term, defined as a set of product characteristics and the product's ability to achieve consumer satisfaction. Hooker and Caswell (1996) subdivided quality into various categories: safety, nutritional value, packaging, and processing [4].

Honey has been used as a food, preservative, and medicine for many centuries. As a food, honey is a natural source of energy. Honey has been also used extensively in the cosmetic industry. The antioxidant properties of honey make it an ideal food preservation agent. The major nutritional components of honey are carbohydrates: not only fructose and glucose but also approximately 25 different oligosaccharides have been discovered. In addition, honey contains small amounts of proteins, enzymes, amino acids, minerals, trace elements, vitamins, aromatic compounds, and polyphenols [5] [6]. The flavor, aroma, and color of honey differ depending on the types of flowers from which bees collect nectar. Three forms of honey exist: liquid, partially crystallized, and granulated [7]. Nearly every society on Earth has used honey for many millenniums. The Koran even devoted a special chapter to honey and its uses [8].

Economic theory suggests that income level and honey price play important roles in consumer decision making. Moreover, quality awareness of maintaining a healthy lifestyle and nutrition have become important factors in understanding the honey market and honey consumption trends. Since Ernest Engel first studied the strong relationship between income and food expenditure in 1857, many studies have shown this same relationship [8] [9].

Ghorbani and Khajehroshanaee (2009) surveyed the consumer demand for qualitative factors of honey using the hedonic pricing (HP) model and cross sectional data from a consumer sample [10]. Their results showed that the type of honey as well as its packing conditions, color, aroma, and protraction have positive effects on its price. Arvanitoyannis and Krystallis (2006) confirmed that consumer dietary habits strongly influence health status [11]. Likewise, Vanyi and Csapo (2009) suggested that (in addition to price, food quality, healthy lifestyle, and nutrition) food safety, organic options, and animal welfare awareness influenced consumer decision making [7].

Pocol and Teselios (2012) observed that the high consumption of honey was associated with medium to high income levels [12]. Certainly, the honey consumption motivational spectrum is associated with the product and its perceived benefits. In general, the honey market depends significantly on wealth trends that indirectly indicate the possibility adopting healthy dietary consumption behaviors. Pocol and Marghitas (2007) also investigated consumer behavior and revealed that $8 \%$ of consumers had never used honey, whereas $75 \%$ of consumers used a maximum of $500 \mathrm{~g}$ of honey per year [13].

Honey is a highly regarded product in Saudi Arabia. Saudi families have a remarkable preference for consuming honey. Honey consumption is higher during traditional, religious, and festive occasions, particularly during Ramadan because families prepare more desserts with honey for the evening meal [14].

According to Al-Ghamdi (2007), Saudi Arabia produces approximately 9000 metric tons of honey annually [15]. In general, Saudi consumers prefer Sider honey that is produced locally, and consumers believe it has valuable medicinal properties. However, the average amount of honey available from local producers is too small to satisfy demand. This scarcity requires the country to import large quantities of honey to meet this demand. Saudi Arabia imports more than 12,809 metric tons of table honey annually and exports approximately 3966 tons; thus, the net imports are 8843 tons [16]. Neighboring Yemen supplies Saudi Arabia with a highly desirable type of honey (Ziziphus), and local consumers are willing to pay up to $\$ 190$ per kilogram [14]. The major sup- 
pliers of honey to Saudi Arabia are Germany, the US, Australia, New Zealand, and Turkey. In addition, the country imports relatively inexpensive honey, mainly for industrial uses, from Eastern Europe, Latin America, and Southeast Asia [14].

To successfully market their wares, honey industry enterprises must understand the latest trends in consumer behavior. Moreover, producing a honey that meets the quality demands of consumers and designing appropriate production and marketing policies requires an understanding of the major factors that influence the honey market. The trend of consuming honey as a health food has steadily increased, and it is one of the driving factors of the expected increase in the domestic demand of honey. From a consumer perspective, a lack of sufficient information exists regarding the quality aspects of honey in general and the quality variation between locally produced and imported honey in particular.

Aggregate food consumption and expenditure patterns have been studied in Saudi Arabia with regard to specific food commodities [17]-[20]. However, none of these previous studies treated honey as a separate commodity. This information is important for forecasting Saudi's honey market demand in the future. The present study analyzed the major factors that influence the honey consumption and expenditure patterns of Saudi Arabia's consumers.

\section{Methodology}

The current study collected primary data using questionnaires. Major items included in the questionnaires included family size, education level, annual household income, primary occupation, family and per capita honey consumption, honey quality characteristics, honey outlets, motivations for honey consumption, prices, and the problems associated with honey marketing. The questionnaires were pretested and adjusted before large-scale use.

This study randomly selected 43, 70, 46, 47, 50, 32, and 43 respondents (for a total of 331) from seven major and representative cities: Riyadh, Jeddah, Tayef, Dammam, Tabouk, Aseer, and Jizan, respectively. The respondents were directly interviewed, and variations in location, education level, and primary occupation were considered. The education levels of respondents were balanced: $16.4 \%$ of respondents completed elementary school, 22.7\% completed high school, 27.2\% completed preparatory school, 29.3\% completed university, and $2.1 \%$ had more education. Approximately $39 \%$ of the respondents were self-employed, whereas $48 \%$ were public sector employees, and the remaining $13 \%$ were employed in the private sector.

Quantitative and qualitative data analyses were employed. One-way analyses of variance and $t$-tests were calculated to examine significant variation in honey consumption, expenditure, and the prices paid for various qualities of honey. A honey consumption function was specified and econometrically estimated in semi-log form using economic theory [21]. This function explains how household consumption and expenditures vary in response to variations in household income. An ordinary least square (OLS) multiple regression model was used to econometrically estimate the function. Adequate consumption and expenditure elasticity were estimated for honey, and the estimated elasticity value was used to forecast the expected demand for honey in the Saudi market through 2025.

\section{Results and Discussion}

\subsection{The Socioeconomic Profile of Honey Consumers and Their Rate of Consumption}

The size of the sampled households ranged from 2 to 18 individuals, with an average of 6.6 individuals per family. The average family size of consumers was slightly larger than the national average of 5.84 .

The annual incomes of the respondent households ranged from SR 30,000 to SR 300,000, with an average of SR 101,223 (USD 26,993). The average per capita income ranged from SR 3600 to SR 60,000. The honey consumption rate varied across families (Table 1). The total estimated annual honey consumption per capita ranged from $0.46 \mathrm{~kg}$ to $11.3 \mathrm{~kg}$, with an average of $4.5 \mathrm{~kg}$. This average per capita honey consumption is relatively high compared with that of other countries; this disparity might be due to the relatively high annual average income of Saudis, which is the equivalent of $\$ 27,000$ per household. Saudi Arabia is the fourth largest honey importer in the world after the EU, the US, and Japan (USID, 2012).

\subsection{Honey Prices}

The average retail price of honey ranged from SR 100 to SR 933, with a mean of SR 274 per kg. 
Table 1. Descriptive statistics of variables that affect honey consumption.

\begin{tabular}{ccccc}
\hline Variable & Min & Max & Mean & SD \\
Family size & 2 & 18 & 6.60 & $\mathbf{3 . 0 3}$ \\
Annual household income (SR) & 30,000 & 300,000 & 101,223 & $\mathbf{5 1 , 2 3 0}$ \\
Annual household expenditures on food (SR) & 12,000 & 120,000 & 36,802 & $\mathbf{1 7 , 3 6 1}$ \\
Annual household expenditures on honey (SR) & 600 & 13,200 & 4387 & $\mathbf{2 2 5 6}$ \\
Annual household honey consumption (kg) & 6 & 90 & 26.5 & $\mathbf{1 2 . 5 5}$ \\
Annual per capita income (SR) & 3600 & 60,000 & 17,358 & $\mathbf{9 9 6 7}$ \\
Annual per capita food expenditures (SR) & 2182 & 30,000 & 6043 & $\mathbf{2 8 0 5}$ \\
Annual per capita honey expenditures (SR) & 85.7 & 3300 & 755 & $\mathbf{4 4 4}$ \\
Annual per capita honey consumption (kg) & 0.46 & 11.3 & 4.5 & $\mathbf{2 . 3}$ \\
Average honey price (SR/kg) & 100 & 933 & 274 & $\mathbf{7 3}$ \\
\hline
\end{tabular}

However, the price of honey varied greatly across location and with regard to botanical origin.

The average price of honey in Saudi Arabia is SR 274 per $\mathrm{kg}$ (\$73 per kg), which is 10 times higher than the average price of honey in the US and the EU. The high price of locally produced honey might be due to the imbalance between supply and demand and the desire of consumers to pay high prices for local honeys. The high price of honey is one of the problems faced by honey consumers.

\subsection{Consumer-Reported Characteristics of Honey Quality}

Honey consumers used a wide range of parameters to judge honey quality (Table 2). The analysis showed that consumers' quality characterizations varied based on the relative significance of taste, aroma, physical state (liquid/crystallized), color, and other characteristics. The aggregated average scores for taste, aroma, physical state, and color were $4.58,4.44,3.54$, and 3.28 , respectively. Approximately $66.8 \%$ of consumers reported that taste is highly important when judging honey quality, and 59.8\% suggested that aroma is highly important. Although physical state and color were considered to be important attributes for judging honey quality, other features related to trust regarding the purity and source of the honey, brand name, and confidence in the producer were also important. In general, the honey quality parameters used by consumers were organoleptic and not measurable. Because honey is commonly traded in Saudi Arabia, quality parameters should be mandated to protect consumers from fraud.

\subsection{Major Honey Retail Outlets}

Imported honey was aggregated for the purposes of this analysis, whereas locally produced honeys (i.e., Sider, Sumra, Talah, and other uncommon honeys) were classified based on their botanical origins as separate aggregate varieties. Table 3 displays the major outlets for locally produced and imported honeys as well as their share of the total supply. According to the respondents, producers and specialized stores are the major outlets in Saudi Arabia for Sider, Sumra, and Talah honeys. Producers supply $47 \%, 45 \%$, and $48 \%$ of the total procured Sider, Sumra, and Talah honeys, respectively. During the harvest season, honey auction markets can be found in major cities where producers bring their honeys and sell directly to consumers and dealers.

Specialized honey stores account for $47 \%, 46 \%$, and $41 \%$ of the total procured Sider, Sumra, and Talah honeys, respectively. Specialized stores, supermarkets, and grocers supply $46 \%, 31 \%$, and $14 \%$ of the total procured imported honey, respectively. Because imported honey prices are relatively low, they were widely displayed for consumers at all retail food outlets. Producers directly supply a significant proportion of their products to consumers, and this business decision minimizes intermediary actors in the honey value chain. However, this type of market is not well-structured and inefficient; it primarily depends on personal contacts, which are one of the market challenges of beekeepers. Organizing beekeepers into marketing cooperatives might improve advertising with regard to their products and brand names in a sustainable manner. 
Table 2. Consumer-reported perceptions of the relative importance of honey quality characteristics.

\begin{tabular}{|c|c|c|c|c|c|c|c|}
\hline \multirow[t]{2}{*}{ Characteristic } & \multicolumn{5}{|c|}{ Relative frequency } & \multicolumn{2}{|c|}{ Aggregate score (out of 5) } \\
\hline & Not important & Somewhat important & Important & Very important & Highly important & Mean & SD \\
\hline Taste & & & 8.5 & 24.8 & 66.8 & 4.58 & 0.64 \\
\hline Aroma & 0.3 & 0.6 & 13. 9 & 25.4 & 59.8 & 4.44 & 0.77 \\
\hline $\begin{array}{c}\text { Physical state } \\
\text { (liquid/crystallized) }\end{array}$ & 6.0 & 10.9 & 32.3 & 24.2 & 26.6 & 3.54 & 1.17 \\
\hline Color & 1.5 & 18.4 & 43.5 & 23.6 & 13.0 & 3.28 & 0.96 \\
\hline
\end{tabular}

Table 3. The major outlets of locally produced and imported honeys as well as their relative shares.

\begin{tabular}{|c|c|c|c|c|c|}
\hline \multirow{2}{*}{ Sources } & \multicolumn{4}{|c|}{ Local honeys } & \multirow{2}{*}{ Imported honeys } \\
\hline & Sider & Sumra & Talah & Others & \\
\hline Supermarket (\%) & 1 & 0 & 0 & 8 & 31 \\
\hline Grocery stores (\%) & 2 & 2 & 3 & 4 & 14 \\
\hline Specialized honey stores (\%) & 47 & 45 & 48 & 46 & 46 \\
\hline Natural medical stores (\%) & 3 & 7 & 8 & 8 & 6 \\
\hline Honey producers (\%) & 47 & 46 & 41 & 34 & 3 \\
\hline Total (\%) & 100 & 100 & 100 & 100 & 100 \\
\hline
\end{tabular}

\subsection{Motivations for Purchasing Honey}

According to the respondents, their major motives for purchasing and consuming honey were to use as medicine, food, a sweetener, or for other uses (Table 4). The analysis revealed that medication, food, and sweetening were the major motivations for buying honey in the Saudi market, with aggregate scores of 4.52, 3.71, and 1.52, respectively. The medicinal value of honey accounted for $71.30 \%$ of consumer's desires to purchase honey. Of course, some overlap exists between using honey as a health food and a medicine. The strong motivation to purchase honey for its medicinal value might be associated with the religious belief that honey (which is mentioned repeatedly in the Koran) can be used to treat various disorders.

In addition, approximately $27.19 \%$ of respondents considered honey as an important food purchase.

\subsection{Preferences for Honey Packaging Volume}

This study observed large honey price variations within and among different honeys and packaging volumes. These variations might be due to many factors including the package volume economics of size (i.e., bulk purchases), blending varieties of honeys, brand names, and producer policies. The current study found that the average prices (per $\mathrm{kg}$ ) of locally produced and imported honey generally decreased as packaging volume increased (Table 5). This finding confirms the size economics hypothesis; package size increases predict commodity price decreases due to the decrease in the unit costs that result from large-scale operations. This finding matches that of Sullivan and Sheffrin (2003), who reported that economies of scale occur for various reasons (e.g., the specialization and division of labor; technical, bulk-buying, and spreading overheads; risk bearing economies; market economies of scale; the container principle; and financial economies) [16]. The results also showed that a $1 \mathrm{~kg}$ honey package is considered to be a regular and marketable package size for both imported and locally produced honey in the Saudi market. Imported and locally produced honeys represent approximately $84 \%$ and $61 \%$ of purchased honey. In addition to packing volume, packing information was reported to play a key role in assisting the consumer at the point of sale. In addition to the other economic and commercial roles of packing communication, packing information also provides information regarding ongoing product performance, which influenced future purchasing decisions [22]. 
Table 4. Consumer motivations for purchasing honey in Saudi Arabia in 2012.

\begin{tabular}{cccccccc}
\hline \multirow{2}{*}{ Motive } & \multicolumn{4}{c}{ Relative frequency } & \multicolumn{3}{c}{ Aggregate score (out of 5) } \\
\cline { 2 - 9 } & Not important & Somewhat important & Important & Very important & Highly important & Mean & SD \\
\hline Food & 0.60 & 9.66 & 35.65 & 26.89 & 27.19 & 3.71 & $\mathbf{0 . 9 9}$ \\
Medicine & 1.21 & 3.93 & 7.55 & 16.01 & 71.30 & 4.52 & $\mathbf{0 . 8 9}$ \\
Sweetener & 59.52 & 34.14 & 2.11 & 3.32 & 0.91 & 1.52 & $\mathbf{0 . 7 8}$ \\
\hline
\end{tabular}

Table 5. Average monthly purchased quantities of local and imported honeys according to package volumes in Saudi households, 2012.

\begin{tabular}{ccccccccc}
\hline & \multicolumn{3}{c}{ Local honey } & \multicolumn{2}{c}{ Imported honey } & \multicolumn{2}{c}{ Total } \\
Package & $\begin{array}{c}\text { Purchased quantity } \\
(\mathrm{kg})\end{array}$ & $\%$ & $\begin{array}{c}\text { Price } \\
\text { SR/kg }\end{array}$ & $\begin{array}{c}\text { Purchased quantity } \\
(\mathrm{kg})\end{array}$ & $\%$ & $\begin{array}{c}\text { Price } \\
\text { SR/kg }\end{array}$ & $\begin{array}{c}\text { Purchased quantity } \\
(\mathrm{kg})\end{array}$ & $\%$ \\
\hline $\mathbf{0 . 2 5} \mathbf{~ k g}$ & 0.043 & 3.84 & 286.9 & 0.050 & 4.57 & 40 & 0.093 & 4.19 \\
$\mathbf{0 . 5} \mathbf{~ k g}$ & 0.350 & 31.13 & 294.8 & 0.043 & 3.11 & 30 & 0.393 & 17.71 \\
$\mathbf{1} \mathbf{~ k g}$ & 0.685 & 60.94 & 220.5 & 0.918 & 83.84 & 25 & 1.603 & 72.24 \\
$\mathbf{2} \mathbf{~ k g}$ & 0.016 & 1.42 & 210.48 & 0.084 & 7.67 & 25 & 0.100 & 4.51 \\
$\mathbf{5} \mathbf{~ k g}$ & 0.030 & 2.67 & 150 & 0.000 & 0.00 & - & 0.030 & 1.35 \\
Total & 1.124 & 100 & $244.15^{*}$ & 1.095 & 100 & $25.88^{*}$ & 2.219 & 100 \\
\hline
\end{tabular}

${ }^{*}$ Weighted average price.

\subsection{Investigating the Variation among Basic Honey Marketing Elements}

\subsubsection{Factors That Affect Honey Consumption and Expenditures}

The results indicated that (except for education level) all factors mentioned below (Table 6) significantly affected honey consumption and expenditures. Consumers in Jeddah were those who consumed the most honey per capita (460 g), whereas consumers in Dammam purchased less honey (214 g).

Per capita honey consumption increased significantly as family income level increased; people with high incomes consume more honey than those with lower incomes. Average per capita honey consumption increased as the family size decreased. The positive association between honey consumption and income level as well as the absence of a correlation between consumption and education level is likely related to the high price of honey in Saudi Arabia; only families with high incomes can afford to consume honey.

The negative relationship between family size and per capita honey consumption might be due to the decrease of average per capita income associated with increases to family size or the effect of family size on per capita income level and subsequent honey consumption. Similarly, the significant correlation between other high value food items (e.g., meat) and annual household income has been well documented [23] [24].

\subsubsection{Factors That Affect Honey-Purchasing Motivations}

Location, family food expenditures, family size, and primary occupations significantly affected honey-purchasing motivations (Table 7). Moreover, honey-purchasing motivations significantly differed across regions and family size. The motivation to purchase honey as a medication was much stronger for smaller compared with larger families. The average motivation scores for purchasing honey as a medication for small, medium, and large families were 4.7, 4.5, and 4.01, respectively. The estimated least significant difference (LSD; 0.15) confirmed the significant differences among family sizes. Medication is a stronger purchasing motivation in certain regions compared with others. For example, the motivation to purchase honey as medication was significantly higher in Jeddah, Tayef, and Tabouk compared with other areas. This result might be due to the trust that these regions have in honey producers and these consumers' abilities to differentiate honey quality attributes. Although family income significantly and positively affects per capita honey consumption (see Table 6), it does not significantly influence motivation (Table 7). This result might be better interpreted by collapsing across different motivations to compute per capita honey consumption. 
Table 6. Factors that cause variations in per capita honey consumption and expenditures each month.

\begin{tabular}{|c|c|c|c|}
\hline Factor & Level & Per capita honey consumption (g) & Per capita honey expenditures (SR) \\
\hline \multirow{11}{*}{ Location } & Riyadh & 346 & 62 \\
\hline & Jeddah & 460 & 7 \\
\hline & Tayef & 372 & 75 \\
\hline & Dammam & 214 & 33 \\
\hline & Tabouk & 269 & 56 \\
\hline & Aseer & 252 & 51 \\
\hline & Jizan & 372 & 40 \\
\hline & $F$ & $17.4^{* *}$ & $10.94^{* *}$ \\
\hline & LSD & 0.30 & 5.9 \\
\hline & Low (1) & 246 & 34 \\
\hline & Average (2) & 369 & 55 \\
\hline \multirow[t]{5}{*}{ Household income level } & High (3) & 415 & 85 \\
\hline & $\mathrm{F}$ & $2.676^{* *}$ & $5.583^{* *}$ \\
\hline & LSD & 0.23 & 5 \\
\hline & Low (4) & 220 & 39 \\
\hline & Average (5) & 352 & 53 \\
\hline \multirow[t]{5}{*}{ Household food expenditure } & High (6) & 280 & 57 \\
\hline & $\mathrm{F}$ & $4.05^{* *}$ & $4.03^{* *}$ \\
\hline & LSD & 0.29 & 5.93 \\
\hline & Small & 533 & 87 \\
\hline & Average & 400 & 65 \\
\hline \multirow[t]{5}{*}{ Family size } & Big & 180 & 180 \\
\hline & $\mathrm{F}$ & $3.69^{* *}$ & $1.97^{* *}$ \\
\hline & LSD & 0.29 & 5.9 \\
\hline & Less than secondary & 360 & 56 \\
\hline & Secondary & 292 & 51 \\
\hline \multirow[t]{5}{*}{$\begin{array}{l}\text { Education } \\
\text { Level }\end{array}$} & University or higher & 330 & 57 \\
\hline & $\mathrm{F}$ & 1.65 & 0.89 \\
\hline & LSD & & \\
\hline & Public sector & 349 & 58 \\
\hline & Private sector & 215 & 39 \\
\hline \multirow[t]{3}{*}{ Primary occupation } & Self-employed & 353 & 59 \\
\hline & $\mathrm{F}$ & $13.01^{* *}$ & $8.45^{* *}$ \\
\hline & LSD & 0.33 & 6.5 \\
\hline
\end{tabular}

(1) Less than SR 5500/month; (2) SR 5500 - 10,000/month; (3) Greater than SR 10,000/month; (4) Less than SR 2500/month; (5) SR 2500 5000/month; (6) Greater than SR 5000/month; ** Significant below the 0.01 threshold; *Significant below the 0.05 threshold. 
Table 7. Factors that cause variations in honey purchasing motivation scores.

\begin{tabular}{|c|c|c|c|c|c|}
\hline \multirow{2}{*}{ Factor } & \multicolumn{5}{|c|}{ Motivation score } \\
\hline & Level & Food & Medicine & Sweetener & Other \\
\hline & Riyadh & 3.40 & 4.55 & 1.72 & 4.80 \\
\hline & Jeddah & 4.20 & 4.94 & 1.55 & $\mathbf{0}$ \\
\hline & Tayef & 3.20 & 4.95 & 1.50 & 4.77 \\
\hline & Dammam & 3.44 & 2.29 & 1.70 & $\mathbf{0}$ \\
\hline \multirow[t]{7}{*}{ Location } & Tabouk & 3.06 & 4.86 & 1.70 & 3.0 \\
\hline & Aseer & 3.88 & 3.91 & 1.13 & 4.65 \\
\hline & Jizan & 4.49 & 3.65 & 1.16 & 2.55 \\
\hline & $\mathrm{F}$ & $19.09^{* *}$ & $12.32^{* *}$ & $4.05^{* *}$ & $16.6^{* *}$ \\
\hline & LSD & 0.15 & 0.13 & 0.13 & 0.30 \\
\hline & Low (1) & 3.80 & 4.50 & 1.70 & 4.20 \\
\hline & Average (2) & 3.70 & 4.60 & 1.50 & 4.30 \\
\hline \multirow[t]{5}{*}{ Household income level } & High (3) & 3.50 & 4.70 & 1.20 & 4.60 \\
\hline & $\mathrm{F}$ & 1.39 & 1.23 & 1.38 & .935 \\
\hline & LSD & - & - & - & - \\
\hline & Low (4) & 3.50 & 4.50 & 1.50 & 4.50 \\
\hline & Average (5) & 3.70 & 4.40 & 1.40 & 4.40 \\
\hline \multirow[t]{5}{*}{ Household food expenditure } & High (6) & 3.80 & 4.10 & 2.10 & 2.30 \\
\hline & $\mathrm{F}$ & 0.79 & 1.20 & $3.09^{* *}$ & $2.17^{*}$ \\
\hline & LSD & & & 0.13 & 11 \\
\hline & Small & 3.60 & 4.70 & 1.60 & 4.80 \\
\hline & Average & 3.60 & 4.50 & 1.50 & 4.01 \\
\hline \multirow[t]{5}{*}{ Family size } & Big & 3.70 & 4.01 & 1.40 & 3.90 \\
\hline & $\mathrm{F}$ & 1.36 & $2.46^{* *}$ & 0.97 & $1.94^{*}$ \\
\hline & LSD & & 0.15 & & 0.34 \\
\hline & Less than secondary & 3.70 & 4.30 & 1.40 & 4.10 \\
\hline & Secondary & 3.50 & 4.60 & 1.50 & 4.60 \\
\hline \multirow[t]{5}{*}{ Education level } & University or higher & 3.70 & 4.50 & 1.60 & 4.70 \\
\hline & $\mathrm{F}$ & 0.68 & 2.19 & 1.13 & $2.60^{*}$ \\
\hline & LSD & & & & 0.36 \\
\hline & Public sector & 3.60 & 4.60 & 1.50 & 4.30 \\
\hline & Private sector & 3.60 & 4.50 & 1.50 & 4.60 \\
\hline \multirow[t]{3}{*}{ Primary occupation } & Self-employed & 3.70 & 4.30 & 1.50 & 4.10 \\
\hline & F & 0.49 & $3.33^{*}$ & 0.082 & 0.35 \\
\hline & LSD & & 0.13 & & \\
\hline
\end{tabular}

(1) Less than SR 5500/month; (2) SR 5500 - 10,000/month; (3) Greater than SR 10,000/month; (4) Less than SR 2500/month; (5) SR 2500 5000/month; (6) Greater than SR 5000/month; * Significant below the 0.01 threshold; *Significant below the 0.05 threshold. 


\subsection{Consumption Function of Honey and Market Prediction}

Based on primary data collected from consumers from various areas of Saudi Arabia, the honey consumption function was estimated as the following:

$$
\begin{aligned}
& Y_{1}=-4.13+0.595255 \ln \beta_{1}+0.582457 \ln \beta_{2} \\
& \quad(-4.32)^{* * * *} \quad(5.3)^{* * * *} \quad(2.6521)^{* * * *} \\
& R^{2}=0.17, \quad F=35.35
\end{aligned}
$$

Abbreviations:

$Y_{1}=$ household honey consumption per month $(\mathrm{kg})$.

$\ln =$ Natural logarithm.

$\beta_{1}=$ Household income per month (SR).

$\beta_{2}=$ Family size (the number of individuals in the family).

Values within parentheses represent the t-values of the regression coefficients.

${ }^{* * *}$ Significant below the 0.01 threshold.

The estimated semi-log function of honey consumption supports the economic theory regarding resultant income elasticity; specifically, honey consumption decreases as family income level increases. The estimated honey consumption elasticity value at the average family income level was 0.27 . This result suggests that honey consumption is elastic, which supports the hypothesis that honey is a basic and necessary food item in the Saudi market. This result suggests that a $10 \%$ increase to the average Saudi family income would increase family honey consumption by $2.7 \%$. This conclusion matches the findings of Alali (2008), who reported similar trends for other foods; consumption elasticity ranged from 0.11 (red meat) to 0.512 (drinks) [25].

Given Al-Ghamdi's (2007) realistic estimates of the annual honey production (approximately 9000 tons), honey imports (12,809 tons), and honey exports (3966 tons) of Saudi Arabia in 2010, the total quantity of honey available for consumption is 17,843 tons [15].

The 2010 Saudi population of 27.562 million people consumed this quantity of honey. The average annual per capita share of honey available for consumption was estimated to be $0.579 \mathrm{~kg}$. The real domestic gross product of Saudi Arabia was approximately SR 1,067,092 in 2010. This means that actual monthly per capita income was approximately SR 3226 in 2010 (SR 21,294 per family; Ministry of Economics and Planning, 2010). Using a double exponential model to forecast the population and the real gross domestic product of Saudi Arabia (where $1999=100$ ), the Saudi population is expected to reach 39.437 million, and the real gross domestic product is expected to reach SR 2.489 billion (fixed at 1999 prices) by 2025 (Ministry of Economics and Planning, 2010). According to this information, the actual monthly per capita income is expected to reach SR 5250, and the average monthly family income is expected to be approximately SR 34,650 (nearly 63\% more than that of 2010). The estimated income/consumption elasticity of 0.27 was used to forecast the expected demand for honey in the Saudi market. Due to this family income increase, household honey consumption is expected to increase by approximately $17 \%$, and average family honey consumption is expected to reach $0.677 \mathrm{~kg}$.

The total market demand for honey in Saudi Arabia is forecasted to reach approximately 29,784 tons in 2025. This dramatic increase in market demand (a 67\% increase from 2010) is explained by the increases to income level (17\%) and population (50\%).

\subsection{Estimating Honey Quality Elasticity in the Saudi Market}

Economic theory indicates that as household incomes increase, families change their diets and demand foods of greater quality. One empirical study demonstrated that food expenditures increase faster than other expenditures as household income rises, which suggests that consumers with greater incomes purchase more expensive foods [26]. To investigate this hypothesis with regard to honey in Saudi Arabia, the expenditure elasticity for honey was compared with the estimated consumption elasticity $(0.27)$. The honey expenditure function was estimated as follows:

$$
\begin{aligned}
Y_{2}= & 1.442328+0.4538 \ln \beta_{1}+0.158086 \ln \beta_{2} \\
& (3.21)^{*+* * *} \quad(8.65)^{*+* *+} \quad(2.652)^{*+*+*} \\
R^{2}= & 0.24, F=52.7
\end{aligned}
$$


Abbreviations:

$Y_{2}=$ Monthly household expenditures on honey (SR).

$\ln =$ Natural logarithm.

$\beta_{1}=$ Monthly household income (SR).

$\beta_{2}=$ Family size (the number of individuals in the family).

The values within parentheses are t-values of the regression coefficients.

*** Significant at the 0.01 level.

Expenditure elasticity was estimated based on the resulting parameters of the estimated honey expenditure function at an average income level. The honey expenditure elasticity estimate was much higher (1.18) than the honey consumption elasticity (0.27). The greater expenditure elasticity value supports the existence of honey quality elasticity; in other words, people with a greater incomes pay higher prices and seek higher quality honey. Based on these estimated consumption and expenditure elasticities, honey quality elasticity is approximately 0.91 . This result suggests that a $10 \%$ increase in the income level of Saudi families will lead to an approximate 9.1\% increase in honey prices, which consumers should be willing to pay for higher quality honey [26]. This interesting result invites additional detailed analyses to quantify the effect that honey quality attributes have on honey price variations in the Saudi market.

This result also confirms the hypothesis that top-earning households have reached a point in which the income elasticity associated with the demand for quality honey is low. However, the quality elasticity of honey is nearly unitary, which supports the demand for quality honey (and other high-quality products) shown by high-income households. The high quality elasticity of honey is associated with markups for different qualities. This confirms the theoretical determinants of price variations such as consumer price sensitivity, customer-differentiated honey, the marginal cost of production, and the distribution of locally produced honey across consumers who are willing to pay for quality and are likely to induce the higher quality elasticities associated with honey [27]. Compared with the quality elasticity estimates for aggregated food groups by previous studies conducted in the Saudi market (which ranged from 0.018 for grain products to 0.175 for fruits; Alali, 2008, honey quality elasticity is much higher [25]. This result should be considered in modern food retail environments, especially supermarkets. These results provide an organizational framework that might help to predict variations in honey quality elasticities for markets in which empirical estimates of elasticities are unavailable or infeasible to obtain.

\subsection{Honey Marketing Deficiency Points}

From a consumer's point of view, quality and price create marketing problems in Saudi Arabia. Table 8 presents the relative magnitudes of these various marketing problems. Approximately $91 \%$ of respondents reported that low quality of honey is a major problem, and this problem was associated with a relatively high maximum score of 4.9. Approximately $80 \%$ of the sampled consumers reported that the high price of honey was an important problem, which was associated with a score of 4.6. In addition, the lack of competition among suppliers was perceived as an important problem of the honey market; this problem was associated with a score of 4.8. A previous report concluded that product differentiation plays an important role in honey market power [28]-[31]. Certain honey producers and dealers were concerned about honey promotion based on their brand name, given their long history of supplying high-quality, specific, and well-known varieties of honey. Regular inspection and mandatory standards must be in place to protect consumers and assure the quality of honey.

The basic marketing problem scores varied significantly across the studied regions (Table 9). The honey marketing structure (i.e., the lack of competition) was reported to be the most significant problem (i.e., given the highest score) across all regions. High honey prices were considered important (with a high score of 4.0 or more) in Jeddah, Tayef, and Tabouk, whereas the shortage of local producers was given a high score only in Tayef. Finally, the lack of marketing services was given a high score only in Jizan.

\section{Conclusion}

Honey remains a popular product in Saudi Arabia. Purchasing honey directly from producers at open markets remains the dominant trend. The major motivations for consuming honey in Saudi Arabia are its medicinal and nutritional values. Honey quality characterizations are primarily organoleptic. The price of honey in Saudi Arabia is high compared with that in other developed countries and varies depending on location and botanical origin. Consumers prefer to purchase locally produced honeys rather than imported ones. Consumers reported that 
Table 8. Honey marketing problems according to consumers.

\begin{tabular}{|c|c|c|c|c|c|c|c|}
\hline \multirow{2}{*}{ Problem } & \multicolumn{5}{|c|}{ Relative frequency } & \multicolumn{2}{|c|}{$\begin{array}{l}\text { Aggregated score } \\
\quad \text { (out of 5) }\end{array}$} \\
\hline & Not important & Somewhat important & Important & Very important & Highly important & Mean & SD \\
\hline High price & 0.91 & 3.02 & 8.16 & 8.16 & 79.76 & 4.63 & 0.83 \\
\hline $\begin{array}{l}\text { Lack of market } \\
\text { knowledge }\end{array}$ & 4.23 & 29.31 & 32.02 & 28.10 & 6.34 & 3.03 & 1.0 \\
\hline Price variations & 3.63 & 30.51 & 31.72 & 23.26 & 10.88 & 3.07 & 1.06 \\
\hline Low quality & 0 & 0.30 & 0.91 & 7.55 & 91.24 & 4.90 & 0.36 \\
\hline Dealer monopolies & 0.60 & 0.60 & 2.11 & 9.37 & 87.31 & 4.82 & 0.55 \\
\hline $\begin{array}{l}\text { Shortage of local } \\
\text { producers }\end{array}$ & 9.06 & 10.27 & 20.54 & 9.67 & 50.45 & 3.82 & 1.38 \\
\hline $\begin{array}{l}\text { Shortage of specific } \\
\text { varieties }\end{array}$ & 0 & 3.02 & 24.77 & 35.35 & 20.54 & 3.22 & 1.09 \\
\hline $\begin{array}{l}\text { Lack of market } \\
\text { services }\end{array}$ & 3.32 & 6.34 & 16.31 & 18.13 & 55.89 & 4.17 & 1.12 \\
\hline $\begin{array}{l}\text { Irrelevant } \\
\text { advertisements }\end{array}$ & 3.32 & 11.78 & 20.24 & 21.15 & 43.5 & 3.90 & 1.18 \\
\hline Other problems & 0.83 & 0 & 4.13 & 8.26 & 86.78 & 4.80 & 0.59 \\
\hline
\end{tabular}

Table 9. Regional variations in the honey marketing problems reported in Saudi Arabia.

\begin{tabular}{|c|c|c|c|c|c|c|c|}
\hline Location & $\begin{array}{l}\text { High } \\
\text { prices }\end{array}$ & $\begin{array}{c}\text { Lack of market } \\
\text { knowledge }\end{array}$ & $\begin{array}{c}\text { Lack of } \\
\text { competition }\end{array}$ & $\begin{array}{c}\text { Shortage of } \\
\text { local production }\end{array}$ & $\begin{array}{c}\text { Shortage of } \\
\text { specific varieties }\end{array}$ & $\begin{array}{c}\text { Lack of } \\
\text { marketing services }\end{array}$ & $\begin{array}{c}\text { Irrelevant } \\
\text { advertisements }\end{array}$ \\
\hline Riyadh & 4.4 & 3.0 & 4.6 & 3.2 & 3.6 & 3.2 & 2.9 \\
\hline Jeddah & 4.8 & 2.8 & 4.9 & 0.2 & 3.1 & 4.4 & 4.3 \\
\hline Tayef & 4.7 & 3.1 & 4. 9 & 4.6 & 3.4 & 4.0 & 3.9 \\
\hline Dammam & 4.3 & 2.9 & 4.8 & 3.4 & 3.4 & 4.1 & 3.9 \\
\hline Tabouk & 4.5 & 3.1 & 4.7 & 3.7 & 3.2 & 4.3 & 3.4 \\
\hline Aseer & 4.4 & 3.0 & 4.9 & 4.1 & 2.8 & 3.2 & 2.9 \\
\hline Jizan & 4.9 & 3.4 & 4.8 & 3.5 & 3.0 & 4.5 & 4.3 \\
\hline $\mathrm{F}$ & $3.7^{* *}$ & $2.3^{*}$ & $3.2^{* *}$ & $7.1^{* *}$ & $2.4^{* *}$ & $7.1^{* *}$ & $1.9^{* *}$ \\
\hline LSD & 0.14 & 0.14 & 0.11 & 0.07 & 0.23 & 0.18 & 0.19 \\
\hline
\end{tabular}

** Significant below the 0.01 threshold; ${ }^{*}$ Significant below the 0.05 threshold.

quality issues are important honey market problems that require appropriate government interventions. Based on consumption/income elasticity estimates, honey is a basic commodity in the Saudi market. Based on econometric model forecasts, the Saudi market demand for honey is expected to reach approximately 29,784 tons by 2025. The increases in income level (17\%) and population (50\%) explain the dramatic increase in the market demand for honey (67\% above that in 2010).

\section{Acknowledgements}

The KACST and the National Plan for Science and Technology (NPST) of King Saud University (project number 11-AGR1749-02) provided the financial and technical support for this study.

\section{References}

[1] Caswell, J. (1998) Valuing the Benefits and Costs of Improved Food Safety and Nutrition. Australian Journal of Agri- 
cultural and Resource Economics, 42, 409-424. http://dx.doi.org/10.1111/1467-8489.00060

[2] Henson, S. and Traill, B. (2000) Measuring Perceived Performance of the Food System and Consumer Food-Related Welfare. Journal of Agricultural Economics, 51, 388-404. http://dx.doi.org/10.1111/j.1477-9552.2000.tb01238.x

[3] Kettlitz, B. (1999). European Consumers: Expectations about Animal Food Source According to the European Consumer Association. Roche Seminar “The Secret of Good Quality” Food, V1V, Amsterdam.

[4] Hooker, N.H and Caswell, J.A. (1996) Regulatory Targets and Regimes for Safety: A Comparison of North American and European Approaches. In: Caswell, J., Ed., The Economics of Reducing Health Risk from Food, Food Marketing Policy Center, Storrs, 1-17.

[5] Bogdanov, S., Jurendic, T., Sieber, R. and Gallmann, P. (2008) Honey for Nutrition and Health: A Review. Swiss Bee Research Centre, Agroscope Liebefeld-Posieux Research Station ALP, Berne.

[6] Joshi, S.R. (2008) Honey in Nepal: Approach, Strategy and Intervention for Subsector Promotion Income Distribution, German Technical Cooperation/Private Sector Promotion-Rural Finance, Laliptur.

[7] Vanyi, G.A. and Csapo, Z. (2009) Evaluation of Honey Consumption in the Main Cities of the North-Great Plain Region. International Congress on the Aspects and Visions of Applied, Chania, 3-6 September 2009.

[8] Prais, S.J. and Houthakker, H.S. (1971) The Analysis of Family Budgets. 2nd Edition, Cambridge University Press, Cambridge, 1-201.

[9] Davis, C.G. (1982) Linkage between Socioeconomic Characteristics, Food Expenditure Patterns and Nutritional Status of Law Income Household: A Critical Review. American Journal of Agricultural Economics, 64, 1077-1025. http://dx.doi.org/10.2307/1240776

[10] Ghorbani, M. and Khajehroshanaee, N. (2009) The Study of Qualitative Factors Influencing on Honey Consumers Demand: Application of Hedonic Pricing Model in Khorasan Razavi Province. Journal of Applied Sciences, 9, 15971600. http://dx.doi.org/10.3923/jas.2009.1597.1600

[11] Arvanitoyannis, I. and Krystallis, A. (2006) An Empirical Examination of the Determinants of Honey Consumption in Romania. International Journal of Food Science \& Technology, 41, 1164-1176. http://dx.doi.org/10.1111/j.1365-2621.2006.01174.x

[12] Pocol, C.B. and Teselios, C.M. (2012) Socio-Economic Determinants of Honey Consumption in Romania. Journal of Food, Agriculture \& Environment, 10, 18-21.

[13] Pocol, C.B. and Marghitas, L.A. (2007) Marketing Study about Honey Consumption in Romania. Bulletin of the University of Agricultural Sciences and Veterinary Medicine Cluj-Napoca Animal Science and Biotechnologies, 63-64, 191-194.

[14] Shenouda, R. (2004) Saudi Arabia’s Taste for Honey. www.fas.usda.gov/info/agexporter

[15] Al-Ghamdi, A.A. (2007) Beekeeping and Honey Production in Saudi Arabia. 5th Conference of the Arab Beekeepers Association, Tripoli.

[16] Sullivan, A. and Sheffrin, S.M. (2003) Economics: Principles in Action. Pearson Prentice Hall, Upper Saddle River, 157.

[17] Al-Hamoudi, K.A. and Ismaiel, S.M. (1988) The Effects of Major Variables on the Production and Consumption of Eggs in the Kingdom of Saudi Arabia. Journal of College of Agriculture, 10, 231-362.

[18] Ismaiel, S.M. (1990) Food Expenditure Pattern for Saudi and Resident Foreigners in the Kingdom of Saudi Arabia. Journal of King Saud University, Agricultural Sciences, 2, 1-145.

[19] Al-Melhem, F.N. (1989) The Pattern of Consumption Expenditure on Basic Food Commodities in the Kingdom of Saudi Arabia. Agricultural Sciences Journal, 2, 1-15.

[20] Al-Hamoudi, K.A., Ismaiel, S.M. and Mouti, A.M.A. (1998) An Economic Study of the Relation between Income Variation and Food Expenditure in the Kingdom of Saudi Arabia. Saudi Association for Energy Economics, Vol. 1, Riyadh.

[21] Kooreman, P. and Wunderink, S. (1997) The Economics of Household Behavior. Macmillan Press LTD., London.

[22] Dobson, P. and Yadav, A. (2012) Packaging in a Market Economy: The Economic and Commercial Role of Packaging Norwich Business School, University of East Anglia, 28 June 2012. www.britishbrandsgroup.org.uk/library/download/5093a3408e9b4

[23] Ikeme, A.I. (1990) Meat Science and Technology. Africans FEP Publishers, Ibadan, 67-72.

[24] Ekine, D.I., Albert, C.O. and Peregba, T.A. (2012) Expenditure Pattern for Beef Consumption in Selected Households in Southern Nigeria. Developing Country Studies, 2, Published Online.

[25] Alali, A.A. (2008) Estimating Functions Consumption of Staple Food Commodities Rural Families Governorate, AlAhsa, Saudi Arabia. Master's Thesis, Department of Agricultural Economics, Faculty of Agriculture and Food, Univer- 
sity of King Faisal, Al-Ahsa.

[26] Gale, F. and Huang, K. (2007) Demand for Food Quantity and Quality in China. USDA, Economic Research Report No. 32, January, 2007. www.ers.usda.gov

[27] Coibion, O., Liran, E. and Hallak, J.C. (2006) Equilibrium Demand Elasticities across Quality Segments, Research, Seminar in International Economics. Discussion Paper No. 550. The University of Michigan, Michigan 48109-1220. April 2006. http://www.spp.umich.edu/rsie/workingpapers/wp.htm

[28] Ismaiel, S.M. and Alnashwan, O. (2012) Food Marketing Systems: Theoretical Principles and Applications in Saudi Economy. King Saud University Press, Riyadh.

[29] Ministry of Economy and Planning (2010) www.mep.gov.sa

[30] Pocol, C.B. (2008) The Management and the Marketing of Bee Products in Romania and European Union. Ph.D. Thesis, University of Agricultural Sciences and Veterinary Medicine, Cluj-Napoca, 100-110.

[31] Pocol, C.B. and Al Mărghitaş, L. (2010) National and International Trends Regarding Production and Consumption of Honey. Academic Press, ClujNapoca, 41-79. 
Scientific Research Publishing (SCIRP) is one of the largest Open Access journal publishers. It is currently publishing more than 200 open access, online, peer-reviewed journals covering a wide range of academic disciplines. SCIRP serves the worldwide academic communities and contributes to the progress and application of science with its publication.

Other selected journals from SCIRP are listed as below. Submit your manuscript to us via either submit@scirp.org or Online Submission Portal.
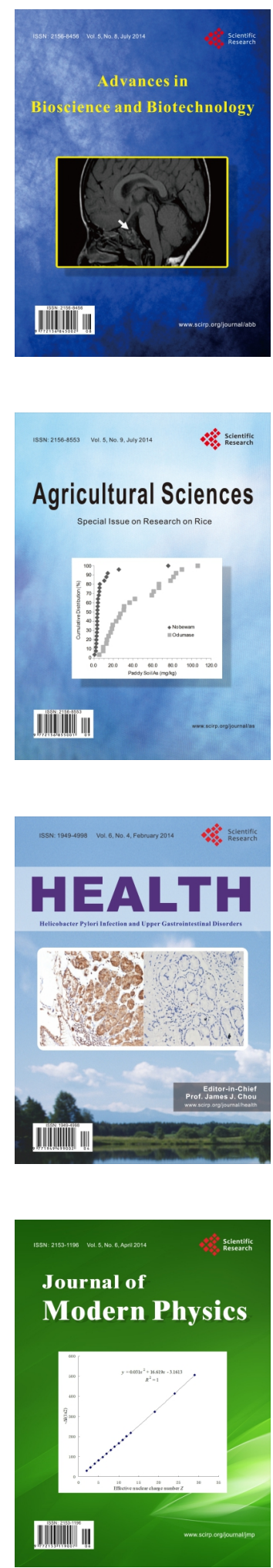
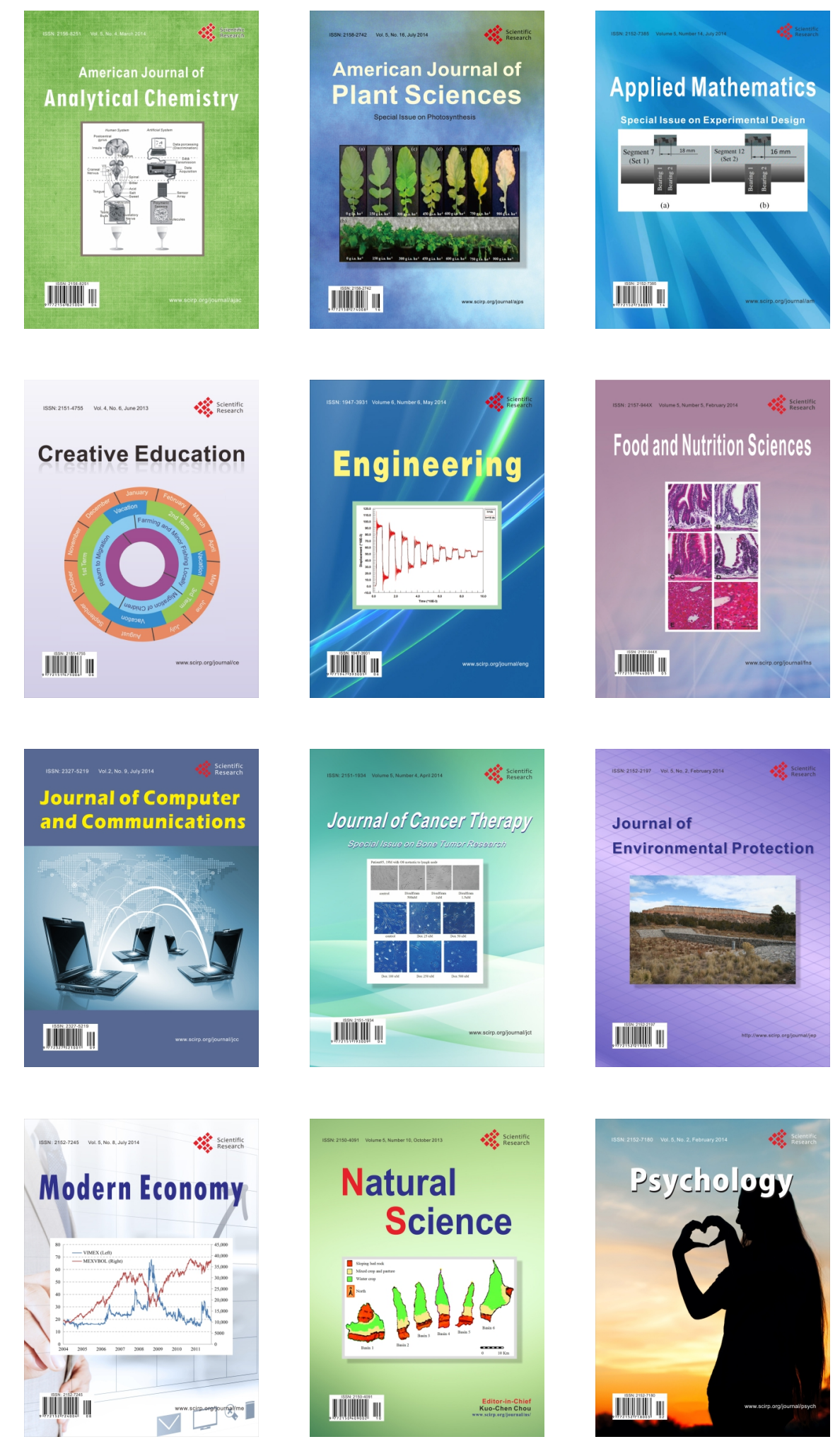